\title{
Statement of Basis/Proposed Plan for the D-Area Burning/Rubble Pits (431-D and 431-1D)
}

by

E. R. Palmer

Westinghouse Savannah River Company

Savannah River Site

Aiken, South Carolina 29808

J. T. Mason

This paper was prepared in connection with work done under the above contract number with the U. S.

Department of Energy. By acceptance of this paper, the publisher and/or recipient acknowledges the U.S. Government's right to retain a nonexclusive, royalty-free license in and to any copyright covering this paper, along with the right to reproduce and to authorize others to reproduce all or part of the copyrighted paper. 


\section{DISCLAIMER}

This report was prepared as an account of work sponsored by an agency of the United States Government. Neither the United States Government nor any agency thereof, nor any of their employees, makes any warranty, express or implied, or assumes any legal liability or responsibility for the accuracy, completeness, or usefulness of any information, apparatus, product, or process disclosed, or represents that its use would not infringe privately owned rights. Reference herein to any specific commercial product, process, or service by trade name, trademark, manufacturer, or otherwise does not necessarily constitute or imply its endorsement, recommendation, or favoring by the United States Government or any agency thereof. The views and opinions of authors expressed herein do not necessarily state or reflect those of the United States Government or any agency thereof.

This report has been reproduced directly from the best available copy.

Available to DOE and DOE contractors from the Office of Scientific and Technical Information, P. O. Box 62, Oak Ridge, TN 37831; prices available from (423) 576-8401.

Available to the public from the National Technical Information Service, U. S. Department of Commerce, 5285 Port Royal Road, Springfield, VA 22161. 


\section{DISCLAIMER}

Portions of this document may be illegible electronic image products. Images are produced from the best available original document. 
United States Department of Energy

Savannah River Site

\section{Statement of Basis/Proposed Plan for the D-Area Burning/Rubble Pits (431-D and 431-1D) (U)}

WSRC-RP-95-905

Revision 1.3

(Changes in boldface)

August 1996

Prepared by:

Westinghouse Savannah River Company

Savannah River Site

Aiken, SC 29808

Prepared for the U. S. Department of Energy under Contract No. DE-AC09-89-SR18035

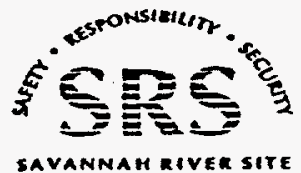




\title{
Disclaimer
}

This report was prepared for the United States Department of Energy under Contract No. DE-AC09-89-SR18035 and is an account of work performed under that contract. Reference herein to any specific commercial product, process, or service by trademark, name, manufacturer or otherwise does not necessarily constitute or imply endorsement, recommendation, or favoring of same by Westinghouse Savannah

River Company or by the United States Government or any agency thereof.

\author{
Printed in the United States of America \\ Prepared for the \\ U. S. Department of Energy \\ by \\ Westinghouse Savannah River Company \\ Aiken, South Carolina
}


Statement of Basis/Proposed Plan for the D-Area Burning/Rubble Pits (431-D and 431-1D)

WSRC-RP-95-905

Savannah River Site, August, 1996

Revision.1.3

APPROVAL PAGE

Revision.1.3 Statement of Basis/Proposed Plan

for the D-Area Burning/Rubble Pits (431-D and 431-1D)

Savannah River Site

Aiken, South Carolina

The attached document was completed under the direction of the Environmental Restoration Department at the Westinghouse Savannah River Company. We have reviewed the document, and to the best of our knowledge, it is true, accurate, and complete.

Date:

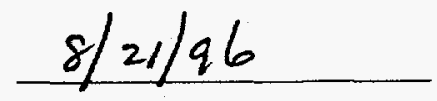

Date:

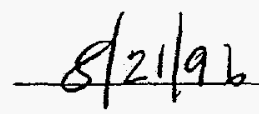

Date:

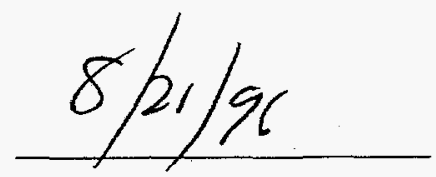

Date:

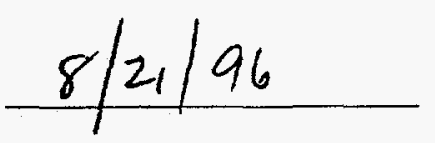

Date:

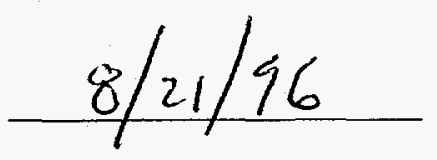

Date:

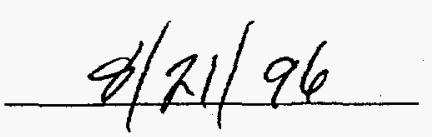

Date: 812196
Signature: Title:

Signature: Title:

Signature: Title:

Signature: Title:

Signature: Title:

Signature: Title:

Signature: Title:

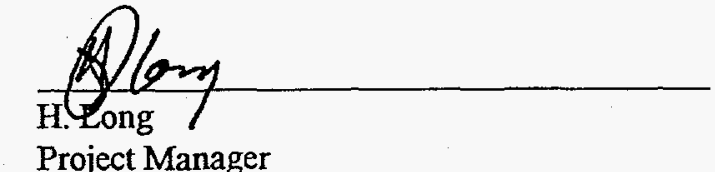

Project Manager

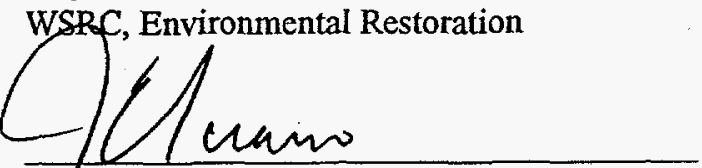

J. E. Sciarro

Manager, D/TNX

WSRC, Environmental Restoration

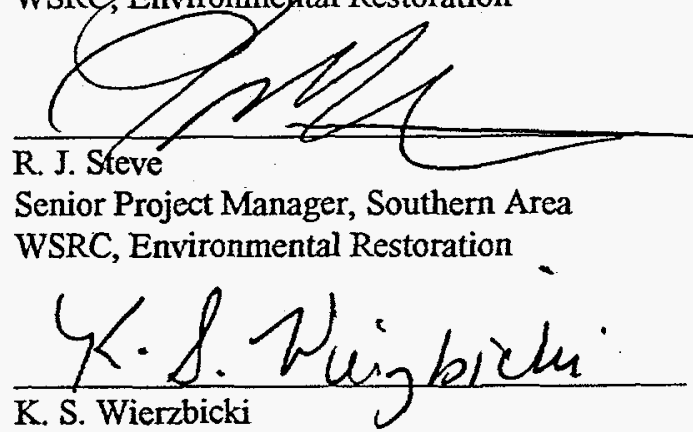

Manager, Environmental Compliance WSRC, Environmental Restoration

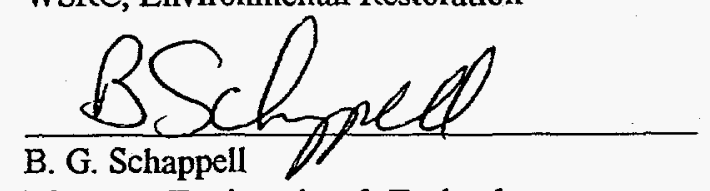

Manager, Engineering \& Technology

WSRC, Environmental Restoration

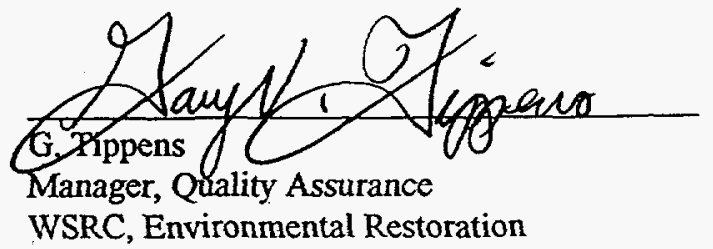

WSRC, Environmental Restoration

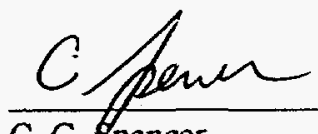

C. G. Spencer

Acting Program Manager

WSRC, Environmental Restoration 


\section{APPROVAL PAGE}

Revision.1.3 Statement of Basis/Proposed Plan

for the D-Area Burning/Rubble Pits (431-D and 431-1D)

\section{Savannah River Site \\ Aiken, South Carolina}

The attached document was completed under the direction of the Environmental Restoration Department at the Westinghouse Savannah River Company. We have reviewed the document, and to the best of our knowledge, it is true, accurate, and complete.

Date:

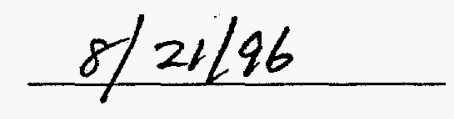

Date:

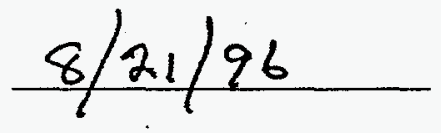

Date: $8 / 21 / 96$

Date: $8 / 21 / 96$
Signature:

Title:

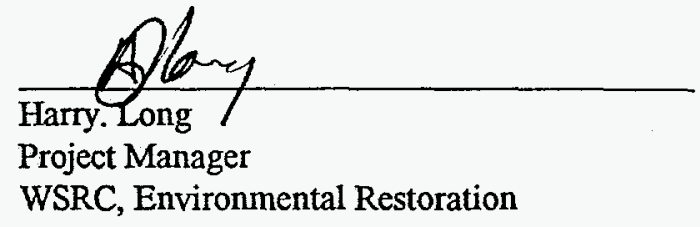

Signature: Title:

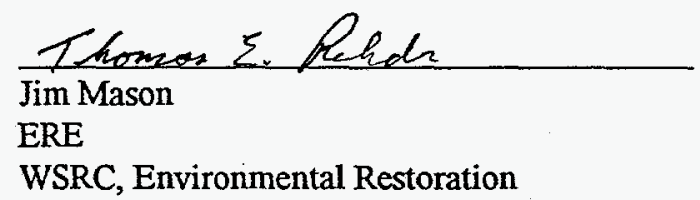

Signature: Title:

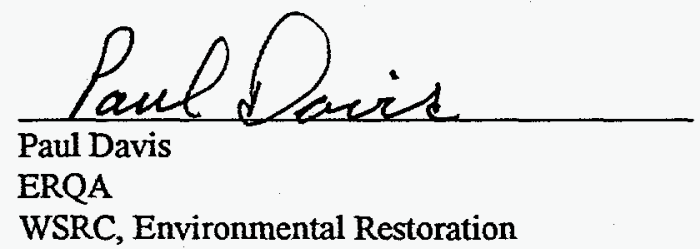

Signature: Title:

Signature: Title:
WSRC, Environmental Restoration

Nilesh Amin

EREC

WSRC, Environmental Restoration

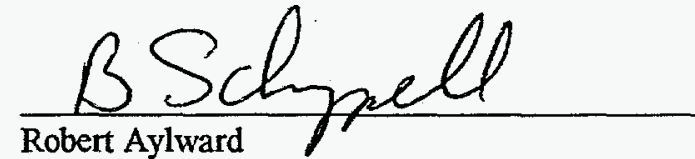

Manager, Technology and Feasibility Study WSRC, Environmental Restoration 


\title{
CERTIFICATION PAGE
}

\author{
Savannah River Site \\ Aiken, South Carolina
}

Revision.1.3 Statement of Basis/Proposed Plan

for the D-Area Burning/Rubble Pits (431-D and 431-1D)

"I certify under penalty of law that this document and all attachments were prepared under my direction or supervision in accordance with a system designed to ensure that qualified personnel properly gather and evaluate the information submitted. Based on my inquiry of the person or persons who manage the system, or those persons directly responsible for gathering the information, the information submitted is, to the best of my knowledge and belief, true, accurate, and complete. I am aware that there are significant penalties for submitting false information including the possibility of fine and imprisonment for knowing violations."

Date:
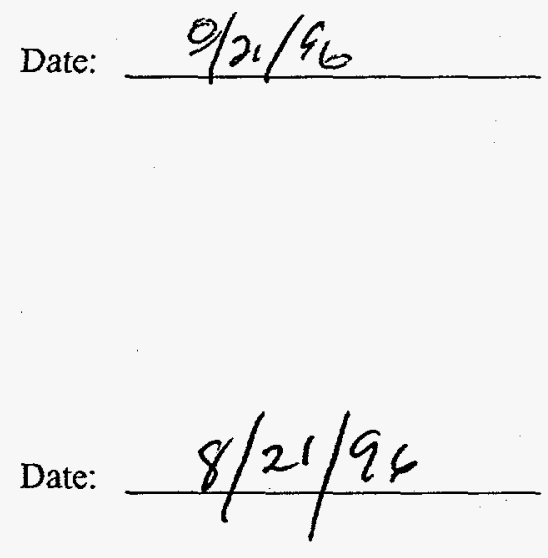

Signature:

Title:
Program Manager

Environmental Restoration

Westinghouse Savannah River Company

Contractor for the U.S. Department of

Energy, Savannah River Operation

Signature: Title: 


\section{Table of Contents}

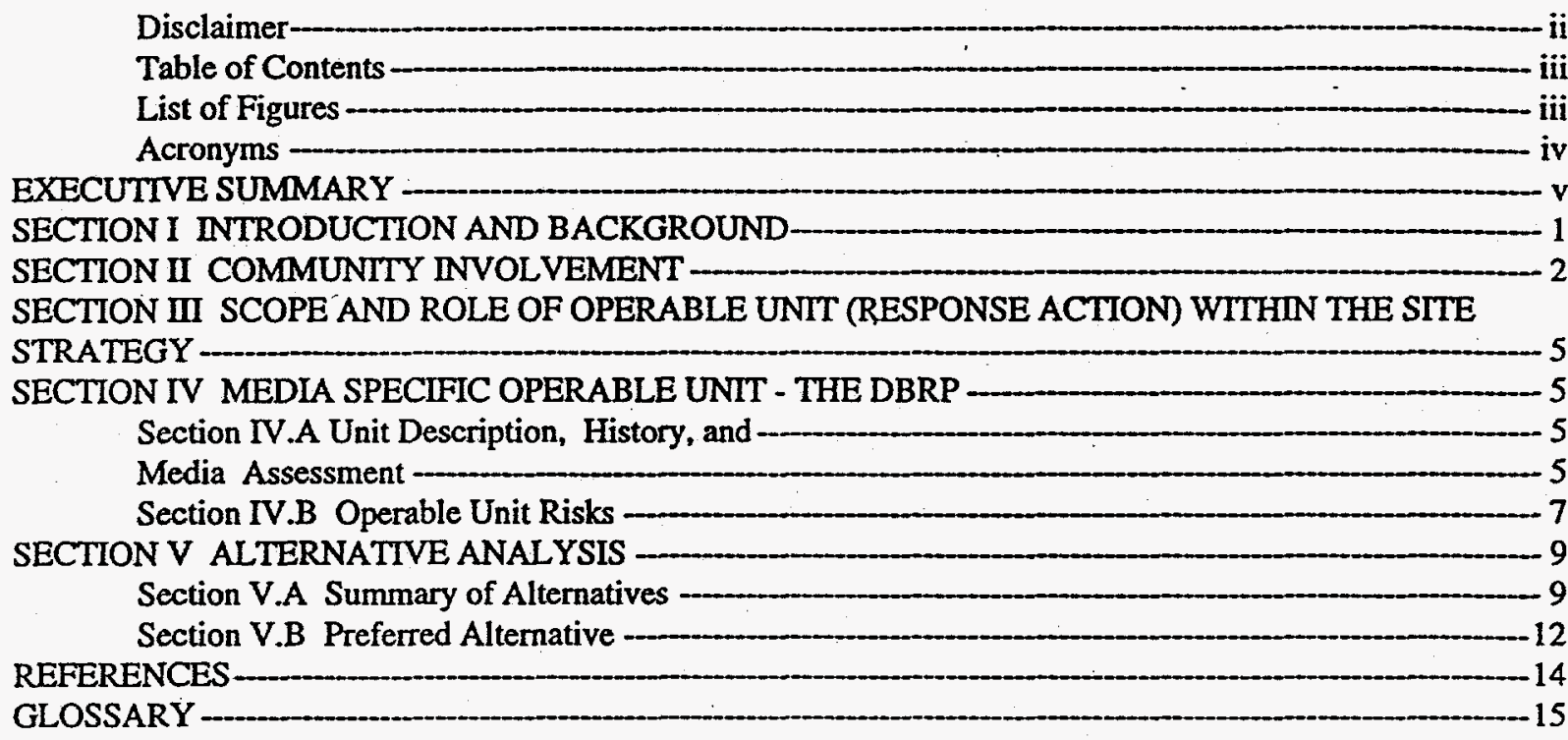

\section{List of Figures}

Figure 1 Location of the D-Area Burning/Rubble Pits in Relation to Major Savannah River Site Facilities 3

Figure 2 Topographic and Water Table Potentiometric Map of the D-Area Burning/Rubble Pits ....................... 4 


\title{
Acronyms
}

\author{
BRA Baseline Risk Assessment \\ CERCLA Comprehensive Environmental Response, Compensation, and Liability Act, 1980 \\ DBRP \\ D-Area Burning/Rubble Pits \\ DOE \\ U. S. Department Of Energy \\ EPA \\ PCB \\ U. S. Environmental Protection Agency \\ Polychlorinated biphenyl \\ RCRA Resource Conservation and Recovery Act, 1976 \\ RFI/RI \\ ROD \\ RCRA Facility Investigation/Remedial Investigation \\ SCDHEC \\ Record of Decision \\ SCHWMR \\ SRS \\ South Carolina Department of Health and Environmental Control \\ WSRC \\ South Carolina Hazardous Waste Management Regulations \\ Savannah River Site \\ Westinghouse Savannah River Company
}




\section{EXECUTIVE SUMMARY}

This Statement of Basis/Proposed Plan is being issued by the U. S. Department of Energy (DOE), which is the lead agency for the Savannah River Site (SRS) remedial activities, with concurrence by the U. S. Environmental Protection Agency (EPA)Region IV and the South Carolina Department Of Health and Environmental Control (SCDHEC).

The purpose of this Statement of Basis/Proposed Plan is to describe the preferred alternative for addressing the D-Area Burning/Rubble Pits (DBRP) (431-D and 431-1D) and to provide an opportunity for public input into the remedial action selection process. R.61-79.124 of the South Carolina Hazardous Waiste Management Regulations (SCHWMR) and Section 117 (a) of the Comprehensive Environmental Response, Compensation and Liability Act (CERCLA) require advertisement of the draft RCRA permit modification and notice of proposed remedial actions (i.e., the Statement of Basis/Proposed Plan).

The DBRP are located approximately 2600 feet west of D-Area in Northwestern Barnwell County, South Carolina, about 2600 feet east of the Savannah River which comprises the western boundary of the SRS. Between 1951 and 1973, the pits were used to burn paper, plastics, wood, rubber, rags, cardboard, oil, degreasers, and spent solvents. After burning was discontinued in 1973, the pits were used to dispose of concrete rubble, bricks, tile, asphalt, plastic, metal, wood products, and rubber. When the pits were filled to capacity in 1983, they were covered with compacted clayrich native soil and vegetation was established.

The Resource Conservation and Recovety Act (RCRA) Facility Investigation/Remedial Investigation (RFI/RI) Report (WSRC, 1995b) and the Baseline Risk Assessment (BRA) (WSRC, 1995a) indicate that the DBRP pose no significant risk to the environment. For an industrial land use scenario, ingestion of soil in the top two foot layer poses a risk of $1 \times 10^{-6}$ from polychlorinated biphenyl-1260 (PCB-1260) (78\% of the associated risk), benzo(a)pyrene (10\% of the associated risk), and octachlorodibenzo-p-dioxin isomers ( $9 \%$ of the associated risk). This risk ( $\left.1 \times 10^{-6}\right)$ represents one excess cancer in a human population of one million and is at the lower limit of EPA's target risk range of $1 \times 10^{-6}$ (one in one million) to $1 \times 10^{-4}$ (one in ten thousand). The hazard index for soil ingestion under the future industrial use scenario is $\mathbf{0 . 0 3}$.

In a residential land use scenario, ingestion of soil in the top two foot layer of soil in the pits poses a risk of $1 \times 10^{-5}$ (one excess cancer in 100,000) predominantly from PCB-1260 (78\% of the associated risk). The hazard index for this scenario is 0.7. These risks are within EPA's target risk range. The Corrective Measures Study/Focused Feasibility Study was conducted to consider actions which could reduce the risk to $1 \times 10^{-6}$.

An extensive suite of treatment alternatives was considered in the F-Area Burning/Rubble Pits (231-F, 23I-1F, and 231-2F) Corrective Measures Study/Feasibility Study (U) (WSRC, 1996a). Similar wastes were managed in both sets of burning/rubble pits under similar conditions and practices; similar chemicals of concern have been recognized for both facilities. Therefore, with EPA and SCDHEC concurrence, SRS conducted the Corrective Measures Study/Focused Feasibility Study (WSRC, 1996b) for the DBRP, reducing the suite of treatment alternatives considered in detail to the following five alternatives:

1 ? . No Action

2. Institutional Controls

$3 \quad$ Native Soil Cover (4')

4 Thermal Desorption/Incineration

5 Offsite Soil Disposal

The preferred alternative for remediating the DBRP is Alternative 2, Institutional Controls, which will preclude future residential use of this land and prohibit excavation of the soil which might expose future workers to low concentrations of hazardous constituents. Institutional Controls will include deed notifications to inform any potential purchasers of the property that the land had been used for waste management and disposal activities. The DBRP are located in an area which has been recommended for industrial use by the Citizens Advisory Board and the Savannah River Site Future Use Project Report (DOE, 1996). Under this land use scenario, the risk from soil ingestion in the pits is $1 \times 10^{-6}$ to future industrial workers. The hazard index is 0.03 . 
Implementation of this alternative will require both short- and long-term actions. For the short-term, signs will be posted indicating that this area was used to manage hazardous materials. In addition, existing SRS access controls will be used to maintain the use of this site for industrial use only.

In the long-term, if the property is ever transferred to non-federal ownership, the U.S. Government will, in compliance with Section 120(h) of CERCLA, create a deed for the new property owner. The deed shall include notification disclosing former waste management and disposal activities as well as remedial actions taken on the site. The deed notification shall, in perpetuity, notify any potential purchaser that the property has been used for the management and disposal of nonhazardous, inert construction debris, and that wastes containing hazardous substances, such as degreasers and solvents, were also managed and burned on the site.

The deed shall also include deed restrictions precluding residential use of the property. However, the need for these deed restrictions may be reevaluated at the time of transfer in the event that contamination no longer poses an unacceptable risk under residential use.

In addition, if the site is ever transferred to nonfederal ownership, a survey plat of the area will be prepared, certified by a professional land surveyor, and recorded with the appropriate county recording agency.

Throughout the period of Federal ownership, as well as for any future ownership, under Institutional Controls (Alternative 2), there will be no risk greater than $1 \times 10^{-6}$ or hazard index greater than 0.03 to future industrial workers. Furthermore, there will be no appreciable risk to the environment.

DOE will draft a plan for continued groundwater monitoring for the chemicals of concern at the DBRP. This plan will be appended to the Record of Decision (ROD). The results of the annual groundwater monitoring program will be reviewed during the five year ROD reviews to determine if there has been any appreciable leaching of the chemicals of concern to the groundwater.

Community involvement in the remedial alternative selection process for the DBRP is strongly encouraged. Section II- includes - SRS and SCDHEC contact information to request a public meeting, to obtain additional information about this Statement of Basis/Proposed Plan, or to submit comments.

All submitted comments will be revilewed and considered prior to final selection of an alternative. A Responsiveness Summary will be prepared to address significant issues raised during the public comment period and it will be made available with the final RCRA permit and the ROD. The final RCRA permit and the ROD document the final decision for the unit. 


\section{SECTION I INTRODUCTION AND BACKGROUND}

\section{Introduction}

This Statement of Basis/Proposed Plan is issued by DOE, which is the lead agency for SRS remedial activities, and with concurrence by EPA and SCDHEC. The purpose of the Statement of Basis/Proposed Plan is to describe the preferred alternative for addressing the DBRP located in northwestern Barnwell County, South Carolina (see Figure 1) and to solicit public comment on the preferred alternative.

SRS manages certain waste materials which are regulated under RCRA, a comprehensive law, requiring responsible management of hazardous waste. RCRA 3004(u) requires that releases from solid waste management units be investigated and remediated as necessary. The DBRP are solid waste management units regulated under RCRA 3004(u).

On December 21, 1989, SRS was included on the National Priorities List. This inclusion created a need to integrate the established RFI Program with CERCLA requirements to provide for a focused environmental program. In accordance with Section 120 of CERCLA, DOE has negotiated a Federal Facility Agreement (1993) with EPA and SCDHEC to coordinate remedial activities at SRS into one comprehensive strategy which fulfills these dual regulatory requirements.

Both RCRA and CERCLA require that the public be given the opportunity to review and comment on the draft permit modification and proposed remedial alternative. Public participation requirements are listed in SCHWMR R.61-79.124 and Sections 113 and 117 of CERCLA. These requirements include establishment of an Administrative Record File that documents the selection of remedial alternatives and allow for review and comment by the public regarding those alternatives (see Section II). The Administrative Record File must be established at or near the facility at issue. The SRS Public Involvement Plan (DOE, 1994) is designed to facilitate public involvement in the decision-making process for permitting, closure, and the selection of remedial alternatives. SCHWMR R.61-79.124 and Section 117(a) of CERCLA require advertisement of the draft permit modification and proposed remedial action and provide the public an opportunity to participate in the selection of a remedial action.

This Statement of Basis/Proposed Plan is a summary of the Administrative Record File leading to selection of the preferred alternative. The Statement of Basis/Proposed Plan presents the preferred alternative and the rationale for selecting that alternative. Community involvement in consideration of this evaluation of alternatives for the DBRP is strongly encouraged. SCHWMR R.61-79.124 requires that a brief description and response to all significant comments be made available to the public as a part of the RCRA Administrative Record. All submitted comments will be reviewed and considered. Following the public comment period, a Responsiveness Summary will be prepared to address significant issues raised during the comment period. The Responsiveness Summary will be made available with the final RCRA permit and the ROD. In order to gain a better understanding of RCRA and CERCLA activities as they pertain to the DBRP, the public is encouraged to review : the Adthinistrative Record File for this unit. Refer to Section II of this document for information regarding availability of and access to the Administrative Record.

The final selection of the remedial alternative under RCRA will be in the form of a final permit modification decision which is made by SCDHEC. The final selection of the remedial alternative, that will satisfy the FFA requirements, will be made by DOE, in consultation with EPA and SCDHEC, only after the public comment period has ended and all comments submitted have been reviewed and considered. It is important to note that the final action may be different than the preferred alternative discussed in this plan, depending on new information or public comments. The alternative chosen will be protective of human health and the environment and comply with all Federal and State environmental laws. 


\section{Background}

SRS occupies approximately 310 square miles of land adjacent to the Savannah River, principally in Aiken and Barnwell Counties of South Carolina. SRS is a secured U. S. Government facility with no permanent residents. SRS is located approximately 25 miles southwest of Augusta, Georgia and 20 miles south of Aiken, South Carolina. Figure 1 shows the location of the DBRP in relation to major SRS facilities.

The Federal Facility Agreement lists the DBRP waste unit (431-D and 431-1D) as a RCRA/CERCLA unit requiring further evaluation using an investigation/assessment process with CERCLA remedial investigation to determine the actual or potential impact to human health and the environment. Figure 2 shows the layout of the DBRP with sample locations and monitoring wells.

\section{SECTION II COMMUNITY INVOLVEMENT}

This document summarizes information that is provided in greater detail in the FFA Administrative Record File, which is available for review by the public at the following locations:

\section{U. S. Department of Energy}

Public Reading Room

Gregg-Graniteville Library

University of South Carolina-Aiken

171 University Parkway

Aiken, South Carolina 29801

(803) 641-3465

\section{Thomas Cooper Library}

Government Documents Department

University of South Carolina

Columbia, South Carolina 29208

(803) $777-4866$

Reese Library

Augusta State University

2500 Walton Way

Augusta, Georgia 30910

(706) $737-1744$
Asa H. Gordon Library

Savannah State University

Thompkins Road

Savannah, Georgia 31404

(912) $356-2183$

The RCRA Administrative Record File for SCDHEC is available for review by the public at the following locations:

The South Carolina Department of Health and Environmental Control

Bureau of Solid and Hazardous Waste Management

8901 Farrow Road

Columbia, South Carolina 29203

(803)896-4000

Lower Savannah District

Environmental Quality Control Office

215 Beaufort St., N. E.

Aiken, South Carolina 29802

(803)641-7670

The public will be notified of a public comment period through mailing of the SRS Environmental Bulletin, a monthly newsletter sent to approximately 3500 citizens in South Carolina and Georgid, and through the Aiken Standard, the Barnwell People Sentinel, the Allendale Citizen Leader, The State, and the Augusta Chronicle newspapers. The public comment period will also be announced on local radio stations.

DOE will provide an opportunity for a public meeting during the public comment period if significant interest is expressed. The public will be notified of the date, time, and location. At the meeting, the proposed action will be discussed and questions about the action will be answered. 
Figure 1 Location of the D-Area Burning/Rubble Pits in Relation to Major Savannah River Site Facilities

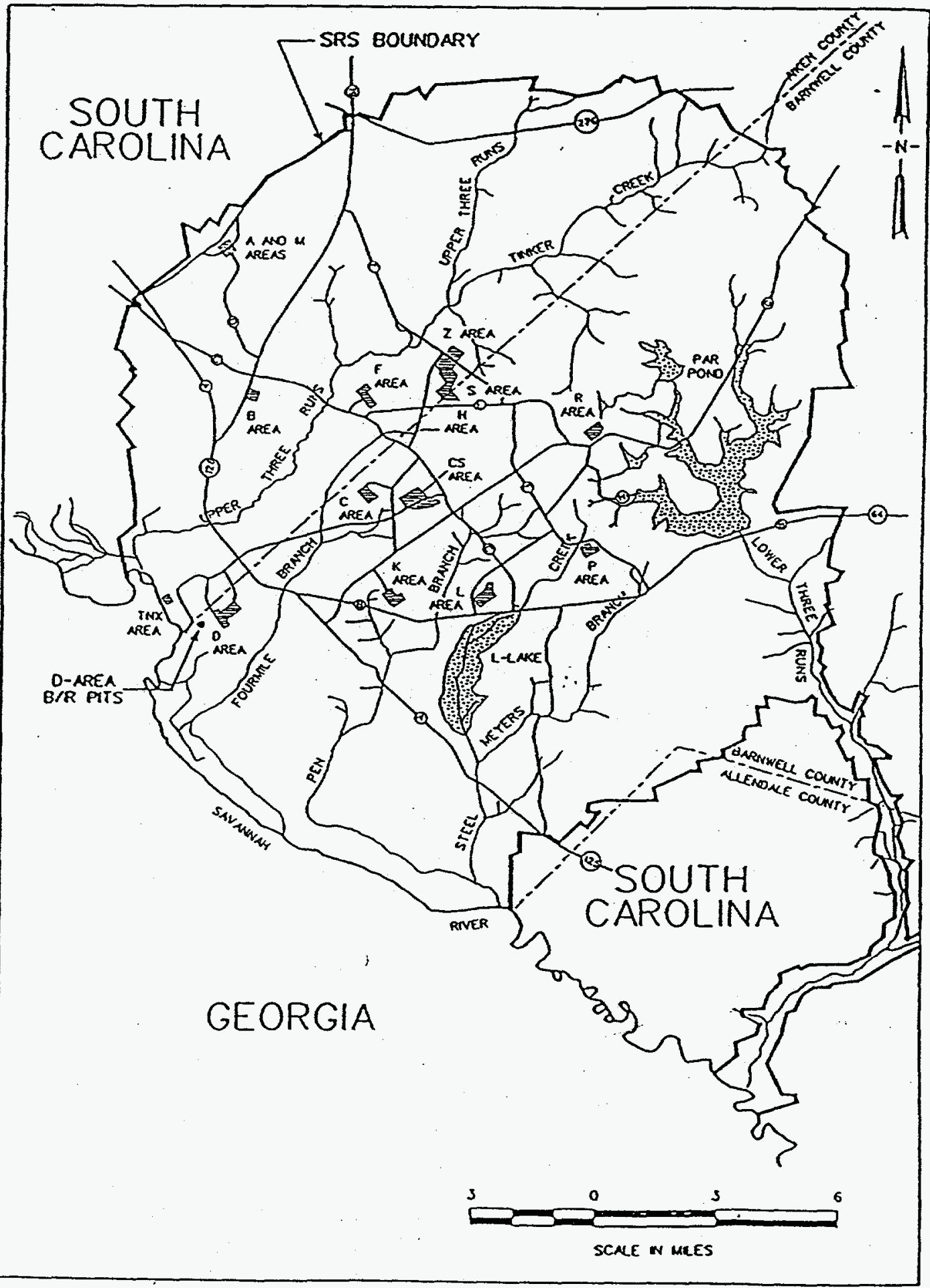


Statement of Basis/Proposed Plan for the D-Area Burning/Rubble Pits (431-D and 431-1D) (U) Savannah River Site, July 1996

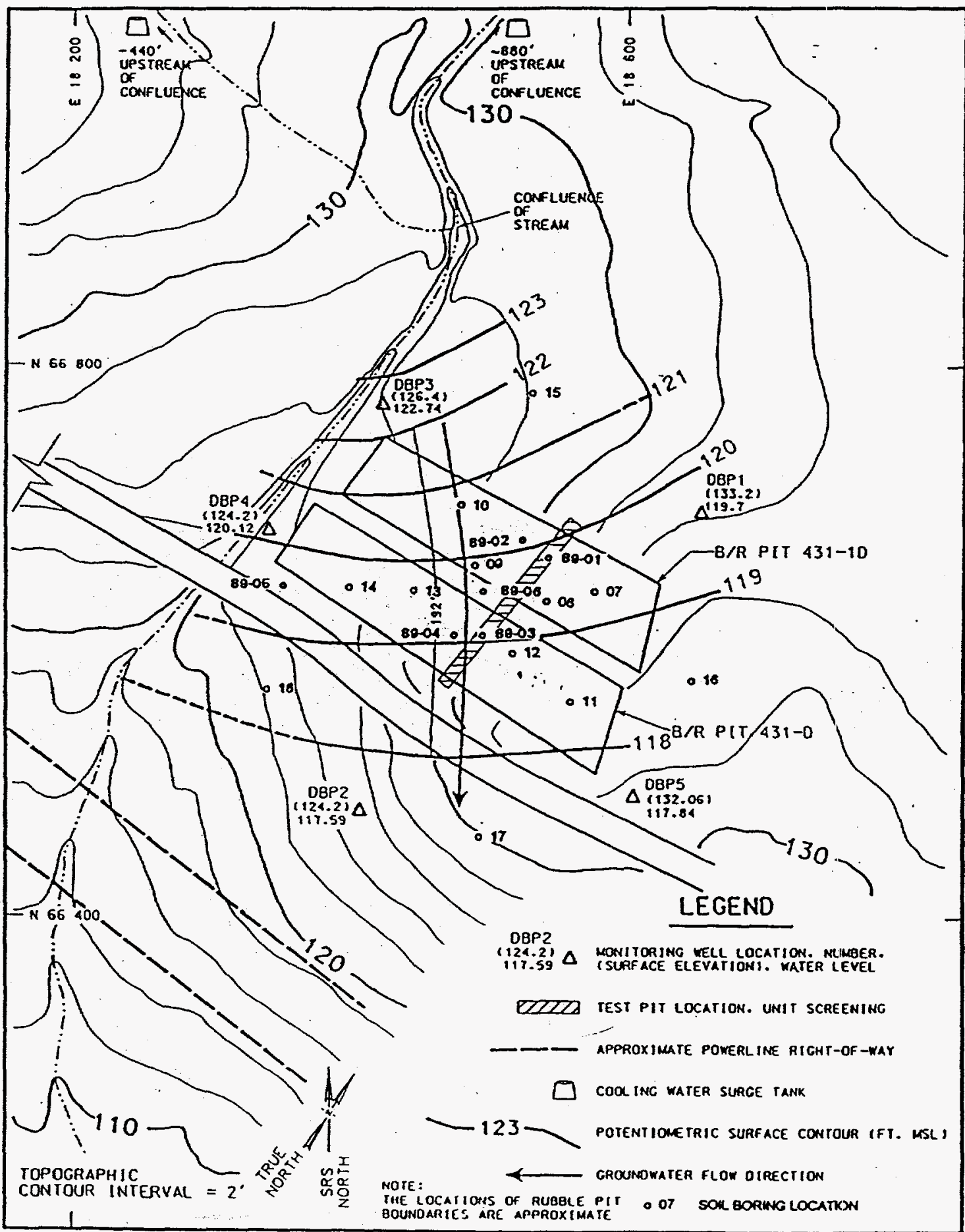

120

$0 \quad 120$

MTDRAIS IC CHADIENT -

VCAIICAL CHANCE IN HEAO IOHI LFI.

-.02 rI./FI.

SCALE IN FEET 
To request a public meeting during the public comment period, to obtain more information concerning this Statement of Basis/Proposed Plan, or to submit written comments contact one of the following:

M. A. Flora

Public Involvement

Westinghouse Savannah River Company

Savannah River Site

Building 730-2B

Aiken, South Carolina 29808

(803) 952-6852

The South Carolina Department of Health and Environmental Control

Attn.: G. Randall Thompson, P. E., Director

Division of Hazardous and Infectious Waste

Bureau of Solid and Hazardous Waste Management

2600 Bull Street

Columbia, South Carolina 29201

(803)896-4000

Following the public comment period, a ROD will be signed and a final decision for the RCRA permit will be issued. The ROD and RCRA permit will detail the remedial alternative chosen for the site and will include responses to oral and written comments received during the public comment period in the Responsiveness Summary.

\section{SECTION III SCOPE AND ROLE OF OPERABLE UNIT (RESPONSE ACTION) WITHIN THE SITE STRATEGY}

The DBRP are a source control operable unit, located within the Savannah River Floodplain Swamp Watershed. Several source control and groundwater operable units within this watershed will be evaluated to determine impacts, if any, to associated streams and wetlands. SRS will manage all source control units to prevent impact to the watershed. The proposed action for the DBRP is intended to be a final action. Upon disposition of all source control and groundwater operable units within this watershed, a final, comprehensive ROD for the watershed will be pursued.
SECTION IV MEDIA SPECIFIC OPERABLE UNIT - THE DBRP

\author{
Section IV.A Unit Description, History, and \\ Media Assessment
}

Unit Description and Location

The DBRP are a RCRA/CERCLA waste unit located within the SRS, approximately 2,600 feet west of D-Area and 1.6 miles west of State Highway 125. The Savannah River and associated swamps are located approximately 2,600 feet west of the pits. The topography of the area is flat and the pits are at an elevation of 130 feet above mean sea level and 45 feet above the Savannah River. The water table is approximately 10 feet below ground surface in the area of the DBRP. Surface drainage is to the west-southwest toward a nearby ephemeral tributary of the Savannah River.

The two contiguous waste pits are designated as 431-D and 431-1D and cover a total area of 0.54 acre. Approximate dimensions of 431-D are 257 feet by 46 feet by 10 feet, and the dimensions of 431-1D are 229 feet by 36 feet by 10 feet. The pits have been backfilled with soil and vegetation has been established on the resulting surface. The pit cover is raised above the surrounding terrain, which is essentially level, to enhance drainage.

\section{History of the Unit}

Between 1951 and 1973, burning pits were used at SRS to bum a variety of hazardous and nonhazardous waste. The chemical composition and volumes of the disposed waste are unknown. Combustible materials, which were burned monthly, included paper, plastics, wood, rubber, rags, cardboard, oil, degreasers, and spent organic solvents. No known or suspected radioactive materials were allowed in the burning pits.

Burning of waste in the SRS pits was discontinued by October 1973. A layer of soil was then placed over the residue in the pits and they were subsequently used as rubble pits. Materials allowed in the rubble pits generally included concrete, bricks, tile, asphalt, plastic, metal, empty drums, wood products, and rubber. When the pits were filled to capacity in 1983 or were no longer 
needed, a 1 to 3 foot layer of clayey soil was placed over the contents and the surface was compacted and mounded. Vegetation was established to reduce erosion.

\section{Media Assessment}

The Data Summary Report (WSRC, 1994), BRA (WSRC, 1995a), RFI/RI Report (WSRC, 1995b), and Corrective Measures Study/Focused Feasibility Study (WSRC, 1996b) contain detailed analytical data for all of the environmental media samples taken in the characterization of the DBRP. These documents are available in the Administrative Record (See Section II).

\section{SOILS}

Analytical data indicate that little or no contamination of the soil outside of the DBRP has occurred. Figure 2 shows the sample locations for the Phase I characterization in 1989 and the Phase II characterization in 1993. The BRA identified the following chemicals of concern:

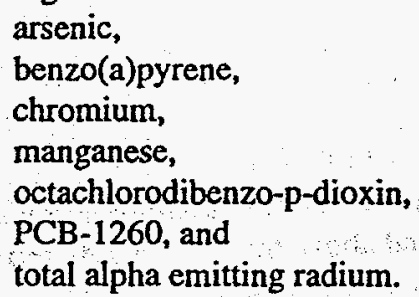

Two times the mean background value for a constituent was used in screening that constituent for consideration as a chemical of potential concern. The mean background value for arsenic at the DBRP is $2.3 \mathrm{mg} / \mathrm{kg}$. In the $0-2$ foot interval of the DBRP, arsenic only exceeds 2 times mean background ( $4.6 \mathrm{mg} / \mathrm{kg}$, parts per million) at one location, boring $7(7.6 \mathrm{mg} / \mathrm{kg})$. Arsenic in the soil at SRS is believed to be primarily the residue of pre-SRS agricultural pesticide application.

In the near-surface soil at the DBRP, chromium only exceeded 2 times mean background (80.8 $\mathrm{mg} / \mathrm{kg})$ in boring $12(339 \mathrm{mg} / \mathrm{kg})$. The chromium present in the DBRP is believed to be predominantly CrIII (chromium in the +3 valence state) which is much less mobile and toxic than the CrVI (chromium+6) assumed in the BRA modeling. CrVI is thermodynamically unstable in soils in the region including SRS and is rapidly reduced to CrIII. Manganese only exceeded 2 times mean background ( $242 \mathrm{mg} / \mathrm{kg}$ ) in the nearsurface interval in boring 11 (260 $\mathrm{mg} / \mathrm{kg})$.

Benzo(a)pyrene did not exceed detection limits in the $0-2$ foot interval at this DBRP. Octachlorodibenzo-p-dioxin, which comprised only $9 \%$ of the risk via ingestion for future on-site workers, was detected at low concentrations in all of the shallow soil samples. Dioxins are products of incomplete combustion. PCB-1260 was identified in only one location, soil boring 12 ; the maximum concentration of PCB-1260, $3.39 \mathrm{mg} / \mathrm{kg}$, was found in the 0.5-2.0 foot interval. 'Total alpha emitting radium was only detected in the $0-2$ foot interval $(1.2 \mathrm{pCi} / \mathrm{g})$ in boring $7 ; 2$ times mean background was $2.49 \mathrm{pCi} g$.

\section{GROUNDWATER}

Groundwater monitoring data indicate that no significant release of hazardous substances to groundwater from the DBRP has occurred. There are 5 monitoring wells in the DBP viell series: DBP-1, -2, -3 (installed in September 1983), DBP4 (installed in June 1984), and DBP-5 (installed in June 1993). Figure 2 shows the locations of the monitoring wells comprising the DBP network and the potentiometric water table map.

Comparison of constituent concentrations, from 1984 through 1992 in the four downgradient DBP wells with concentrations in the upgradient well, DBP-3, indicates little or no. constituent concentration increase in groundwater after flowing beneath the DBRP. The only constituents which show any apparent increase are iron, manganese, lead, sulfate, and possibly gross alpha and total radium. Iron, manganese, and sulfate are covered by the Secondary Drinking Water Standards which deal with the aesthetic properties of public drinking water. The RCRA groundwater protection standard for lead is $0.05 \mathrm{mg} / \mathrm{L}$. The highest value of lead reported for the period of interest was $0.013 \mathrm{mg} / \mathrm{L}$.

Arsenic was the sole contributor to risk under the groundwater ingestion pathway. The risk to the future on-unit worker was $3 \times 10^{-4} ;$ to the future onunit resident the risk was $1 \times 10^{-3}$. The maximum contaminant level for arsenic in drinking water is $0.05 \mathrm{mg} / \mathrm{L}$. Arsenic was only detected once in the DBP monitoring network, the December 1993 
sample from well DBP-5 was reported as 0.044 $\mathrm{mg} / \mathrm{L}$. The following quarter when the well was resampled, arsenic was reported below detection limits of $0.002 \mathrm{mg} / \mathrm{L}$. The risks attributed to this single arsenic value were exaggerated.

Gross alpha and total radium were the only constituents in the Unit Assessment samples (covering three quarters in 1993) for which primary maximum contaminant levels may have been exceeded. The maximum contaminant level for gross alpha is $15 \mathrm{pCi} / \mathrm{L}$, this level may have been exceeded in the December 1993 sample from well DBP-2 ( $15 \mathrm{pCi} / \mathrm{L} \pm 0.21 \mathrm{pCi} / \mathrm{L})$. This gross alpha anomaly occurred only once in a single well that had previously contained no detectable gross alpha and may be due to field or laboratory contamination.

The maximum contaminant level (regulatory standard) for total radium is $5 \mathrm{pCi} /$; an increase to $20 \mathrm{pCi} / \mathrm{L}$ is being considered (56FR33050). Total radium in the groundwater has only exceeded 5 $\mathrm{pCi} / \mathrm{L}$ once since monitoring began at the DBRP. This exceedance occurred in the sample collected from well DBP-2 in December 1993 (the same sample which yielded the gross alpha anomaly); $\mathrm{Ra}-226$ was $4.8 \mathrm{pCi} / \mathrm{L}$ and $\mathrm{Ra}-228$ was $3.5 \mathrm{pCi} / \mathrm{L}$. During modeling performed for the BRA, the assumption was made that all the radium present was Ra-226, the only radium species for which slope factors have been determined and the most toxic radium species. This assumption contributed to an exaggeration of the risk attributed to radium. The ingestion of radium in the groundwater pathway risks was modeled at $6 \times 10^{-6}$ for future workers and $2 \times 10^{-5}$ for future residents. Under current land use (and recommended institutional controls) the on-site visitor is supplied with drinking water from the SRS drinking water supply system. The local groundwater at the DBRP is not used for drinking or hygienic purposes.

\section{Section IV.B Operable Unit Risks}

\section{Human Health Risk Assessment}

As part of the investigation/assessment process for the DBRP waste unit, a BRA was performed using data generated during the assessment phase.
Detailed information regarding the development of chemicals of potential concern, the fate and transport of contaminants, and the risk assessment can be found in the BRA (WSRC, 1995a) and the RFIRI Report for the D-Area Burning/Rubble Pits (43I-D and 431-ID)(U), (WSRC, 1995b).

The process of designating the chemicals of potential concern was based on consideration of background concentrations, frequency of detection, the relative toxic potential of the chemicals, and chemical nutrient status. Chemicals of potential concern are the constituents that are potentially site-related and whose data are of sufficient quality for use in the risk assessment.

An exposure assessment was performed to provide an indication of the potential exposures which could occur based on the chemical concentrations detected during sampling activities. The only current exposure scenario identified for the DBRP was for on-site workers. Conservative future exposure scenarios identified for the DBRP. included future occupational workers and future resident adults and children. The reasonable maximum exposure concentration value was used as the exposure point concentration.

Carcinogenic risks are estimated as the incremental probability of an individual developing cancer over a lifetime as a result of pathway-specific exposure to cancer-causing contaminants. The risk to an individual resulting from exposure to nonradioactive chemical carcinogens is expressed as the increased probability of cancer occurring over the course of a 70 year lifetime. Cancer risks are related to the EPA target risk range of one in ten thousand $\left(1.0 \times 10^{-1}\right)$ to one in one million $(1.0 \times$ $\left.10^{-6}\right)$ for incremental cancer risk at National Priorities List sites. Risk levels at or above the upper-bound of the target risk range $\left(1 \times 10^{-4}\right)$ are considered significant and these sites are expected to undergo remediation.

Non-carcinogenic effects are also evaluated to identify a level at which there may be concern for potential non-carcinogenic health effects. The hazard quotient, which is the ratio of the exposure dose to the reference dose, is calculated for each contaminant. Hazard quotients are summed for each exposure pathway to determine the specific 
hazard index for each exposure scenario. If the hazard index exceeds unity (1.0), there is concern that adverse health effects might occur.

\section{Current Land Use - Noncarcinogenic Hazards}

Under the current land use scenario, human health risks and noncarcinogenic hazards were characterized for the current on-unit visitor. An on-unit visitor is described as an employee of SRS who works at the DBRP for short periods on an infrequent basis, (i.e., a few hours per month performing sampling or maintenance activities). Current on-unit visitors are supplied with drinking water from the on-site drinking water supply system, the local groundwater is not used for drinking or hygiene.

The BRA (WSRC, 1995a) shows that potential adverse noncarcinogenic health effects are not likely to occur, because none of the hazard indices exceeds a value of one.

\section{Current Land Use - Carcinogenic Risks}

Under the current land use scenario, human health risks were characterized for the current on-unit visitor. All of the estimated nonradiological cancer risks were less than $1 \times 10^{-6}$, indicating that carcinogenic risk from the unit is not significant. Media evaluated include soil inside the DBRP, soil outside the DBRP, associated airborne soil particulates, and surface water and sediment in the stream/wetland.

All of the estimated radiological risks were less than $1 \times 10^{-6}$. Radiological risks were estimated for three exposure pathways: ingestion of soil inside the DBRP, inhalation of particulates from soil inside the DBRP, and ingestion of sediment.

\section{Future Land Use - Noncarcinogenic Hazards}

The hazard indices were less than one, indicating adverse noncarcinogenic effects are unlikely for the following pathways:

o direct exposure of adult and child residents to soils inside and outside the DBRP o

direct exposure of child-only residents to soils inside and outside the DERP

o exposure of a child to surface water and sediment

The groundwater ingestion and inhalation pathway yielded a hazard index of 50 from arsenic and manganese to future resident adults and children. This hazard is reduced to 6 for future on-unit workers.

\section{Future Land Use - Carcinogentic Risks}

Several exposure pathways for the future on-unit resident had estimated nonradiological carcinogenic risks exceeding the lower bound of the target risk range, $1 \times 10^{-6}$. No contamination was found in concentrations that yielded risks greater than the upper bound of the risk range of 1 $\times 10^{-4}$ except for arsenic by groundwater ingestion. Under the groundwater ingestion pathway, the risk due to arsenic to the future on-unit worker was $3 x$ $10^{-4}$; to the future on-unit resident the risk was $1 x$ $10^{-3}$. These risks were based on a single arsenic value which was less than the maximum contaminant level for drinking water.

For the future on-unit worker, cancer risks for ingestion of soil from inside the BRPs were equal to the EPA point of departure of $1 \times 10^{-6}$ for the 0 2.0 foot and $0-4.0$ foot depth intervals. Estimated risks for dermal contact with soil and inhalation of soil particulates at both depths inside the DBRP were equal to $1 \times 10^{-6}$.

\section{Ecological Risk Assessment}

Based on characterization of the environmental setting and identification of potential receptor organisms, a conceptual site model was developed to determine the complete exposure pathways through which receptors could be exposed to chemicals of potential concern.

Interpretation of the ecological significance of the unit-related contamination at the DBRP indicated that there was essentially no likelihood of unitrelated chemicals causing significant impacts to the community of species in the vicinity of the unit. 
Site-specific considerations, based on the conclusions of the BRA and RFI/RI, which suggest limited or no potential for significant risk include:

1) The DBRP contain a large volume of buried non-hazardous waste material and cover soil.

2) The levels of contamination recognized during Phase II characterization are generally very low; there is a preponderance of non-detects. The contaminants are very stable chemically and exhibit limited mobility in the soil.

3) The groundwater monitoring program indicates that there has not been significant impact from the waste materials in the pits.

4) The DBRP are in a remote area which has been recommended as a future industrial zone by the Citizens Advisory Board and in the Savannah River Site Future Use Project Report (DOE, 1996).

\section{Remedial Action Objectives}

Remedial action objectives specify unit-specific contaminants, media of concern, potential exposure pathways, and remediation goals. The remedial action objectives are based on the nature and extent of contamination, threatened resources, and the potential for human and environmental exposure. Initially, preliminary remediation goals are developed based upon ARARs, or other information from the RFI/RI Report and the BRA. These goals should be modified, as necessary, as more information concerning the unit and potential remedial technologies becomes available. Final remediation goals will be determined when the remedy is selected and shall establish acceptable exposure levels that are protective of human health and the environment.

Chemicals of potential concern are site- and mediaspecific, man-made and naturally occurring inorganic and organic chemicals, pesticides, and radionuclides detected at a unit under investigation. Chemicals of concern are isolated from the list of chemicals of potential concern by calculating carcinogenic risks and noncarcinogenic hazard indices. A chemical of concern contributes significantly to a pathway having a carcinogenic risk greater than $1 \times 10^{-4}$ and a hazard index greater than 1.0.
Location-specific ARARs must consider Federal, State, and local requirements that reflect the physiographical and environmental characteristics of the unit or the immediate area. Remedial actions may be restricted or precluded depending on the location or characteristics of the unit and the resulting requirements.

None of the risks associated with the soil in the DBRP has been found to be greater than $1 \times 10^{-4}$. PCB-1260 from the 0-2 foot soil interval in Pit 431-D was the predominant risk driver for future residents, contributing $78 \%$ of the $1 \times 10^{-5}$ risk.

The hazard index for this exposure scenario was 0.7 . The only guidance that was exceeded for soil concentrations was for PCB-1260 which had a maximum value of $3.39 \mathrm{mg} / \mathrm{kg}$ in the $0-2$ foot interval of boring 12 in Pit 431-D. The to-beconsidered guidance for PCBs are recommended soil action levels of $1.0 \mathrm{mg} / \mathrm{kg}$ for residential use and 10-25 mg/kg for industrial use (EPA, 1990). The PCB-1260 concentration in Pit 431-D is well below the range for industrial land use.

\section{SECTION V ALTERNATIVE ANALYSIS}

\section{Section V.A Summary of Alternatives}

The RFI/RI and BRA indicate the DBRP pose no significant risk to the environment. The risk to future on-unit workers is only $1 \times 10^{-6}$. Ingestion of soil in the top two foot layer by future residents poses a risk of $1 \times 10^{-5}$, primarily from PCB-1260. This Corrective Measures Study/Focused Feasibility Study was developed to consider possible actions which could reduce the risks to $1 \mathrm{x}$ $10^{-6}$ or less.

A broad suite of treatment alternatives has already been considered in the F-Area Burning/Rubble Pits (23I-F, 23I-IF and 23I-2F) Corrective Measures Study/Feasibility Study (U) (WSRC, 1996a). Both sets of burning/rubble pits received similar wastes which were managed under similar conditions and practices; similar chemicals of concern have been recognized for both facilities. On July 20, 1995, SRS, DHEC, and EPA held a scoping meeting for the DBRP Corrective Measures Study/Feasibility Study. The agenda of this meeting included 
discussion of the site specific considerations and uncertainties, the limited risks associated with the DBRP, and the Citizens Advisory Board proposed industrial land use zones. The conclusion of the scoping meeting was that focusing on a limited suite of altematives in the feasibility study for the DBRP would be appropriate. Therefore, SRS conducted the Corrective Measures Study/Focused Feasibility Study (WSRC, 1996b) for the DBRP, reducing the number of treatment options to be considered to the five alternatives discussed in the following paragraphs.

If the property is ever transferred to private ownership, DOE will create a deed (in compliance with CERCLA 120(h)) for the new property owner with notification of former waste management and disposal activities on the property and any land use or continuing groundwater monitoring commitments or use restrictions.

\section{Alternative I No Action}

Under this alternative, no action would be taken at the DBRP. EPA policy and regulations require consideration of a no action alternative to serve as a basis against which other alternatives can be compared. Because no further action would be taken and the DBRP would remain in their present condition, there are no costs associated with this alternative and there would be no reduction of risk. Potential risks of $1 \times 10^{-5}$ due to soil ingestion and $1 \times 10^{-3}$ from ingestion and inhalation of groundwater would remain for possible future residents.

\section{Alternative 2 Institutional Controls}

Under this alternative, institutional controls would be implemented at the DBRP. Implementation of this alternative will require both short- and long-term actions. For the short-term, signs will be posted indicating that this area was used to manage hazardous materials. In addition; existing SRS access controls will be used to maintain the use of this site for industrial use only.

In the long-term, if the property is ever transferred to non-federal ownership, the U.S.
Government will, in compliance with Section 120(h) of CERCLA, create a deed for the new property owner.' The deed shall include notification disclosing former waste management and disposal activities as well as remedial actions taken on the site. - The deed notification shall, in perpetuity, notify any potential purchaser that the property has been used for the management and disposial of nonhazardous, inert construction debris, and that wastes containing hazardous substances, such as degreasers and solvents, were also managed and burned on the site.

The deed shall also include deed restrictions precluding residential use of the property. However, the need for these deed restrictions may be reevaluated at the time of transfer in the event that contamination no longer poses an unacceptable risk under residential use.

In addition, if the site is ever transferred to nonfederal ownership, a survey plat of the area will be prepared, certified by a professional land surveyor, and recorded with the appropriate county recording agency.

There are no construction costs associated with this alternative. The cost for surveying the land and filing "with" the Barnwell County Records is estimated to be $\$ 2,000$. If five year reviews of remedy are required, the estimated present value for these reviews over the next 30 years is $\$ 8,000$. The total present value costs for Alternative 2 are $\$ 10,000$.

With essentially no further action except for the modest cost of deed notifications and restrictions upon transfer of the land and five year reviews, under Alternative 2 Institutional Controls, risks attributable to future workers at the DBRP would be $1 \times 10^{-6}$.

\section{Alternative 3 Native Soil Cover (4')}

A four foot thick cover of native soil would be installed over the present surface of the DBRP to reduce the likelihood that future excavation for construction of a typical basement would expose waste or contaminated soil. If the property is ever transferred to private ownesship, in 
compliance with CERCLA 120(h), the U. S. Government will create a deed with notifications and restrictions similar to those identified in Alternative 2. Future deed restrictions on excavation below four feet would be necessary to prevent potential exposure of future workers or residents to buried waste which may contain low concentrations of hazardous constituents.

The preparation of a Remedial Design/Remedial Action Work Plan would cost $\$ 50,000$. The construction costs associated with this alternative are estimated at $\$ 160,000$ for the installation of a four foot thick native soil cover. The cost for surveying the land and filing with the Barnwell County Records is estimated to be $\$ 2,000$. Maintenance costs for 30 years are estimated at $\$ 15,000$. If five year reviews of remedy are required, the estimated present value for these reviews over the next 30 years is $\$ 8,000$. Total present value costs for this alternative are estimated at $\$ 235,000$.

With deed restrictions upon the transfer of the land to non-federal ownership per Section 120(h) of CERCLA, the risk to future workers and possible future residents would be reduced to less than $1 \times 10^{-6}$. The need for the deed restrictions will be reevaluated prior to transfer.

\section{Alternative 4 Thermal Desorption/ Incineration}

Under this alternative, the upper two feet of contaminated soil would be excavated for treatment to eliminate the PCB-1260, benzo(a)pyrene, and octachlorodibenzo-p-dioxin isomers. The soil would be fed through a high temperature rotary kiln to extract the volatile organic contaminants from the soil. The extracted gases would then be destroyed in the incinerator. The treated soil would be returned to the site and vegetation would be established to prevent erosion. If the property is ever transferred to private ownership, in compliance with CERCLA 120(h), the U. S. Government will create $a$ deed with notifications and restrictions similar to those identified in Alternative 2. Future deed restrictions (upon transfer of the land to nonfederal ownership) on excavation below two feet would be necessary to prevent potential exposure of future workers or residents to buried waste which may contain low levels of hazardous constituents. The need for these deed restrictions may be reevaluated at the time of transfer in the event that contamination no longer poses an unacceptable risk under residential use.

Preparation of the Remedial Design/Remedial Action Work Plan to implement this alternative would cost "\$150,000. A National Emission Standards for Hazardous Air Pollutants permit would be required at a cost of $\$ 150,000$ because of the potential for atmospheric releases during remediation. The treatment cost for this alternative would be $\$ 1,500,000$ and the deed restriction on excavation below two feet would cost $\$ 2,000$ for a total cost of $\$ 1,502,000$.

This alternative is protective of human health and would permanently reduce risk to less than $1 \times 10^{-6}$ for ingestion of soil from PCB-1260.

\section{Alternative 5 Offsite Soil Disposal}

Under this alternative, the upper two feet of contaminated soil would be excavated and transported to a licensed offsite disposal facility. The excavation would be filled to grade with clean native soil and cover vegetation would be established. If the property is ever transferred to private ownership, in compliance with CERCLA $120(\mathrm{~h})$, the U. S. Government will create a deed with notifications and restrictions similar to those identified in alternative 2 . The potential risk for exposure of future workers and possible residents to low concentrations of hazardous constituents in the remaining waste would necessitate the filing of a deed restriction on excavation below two feet upon the transfer of the land to non-federal ownership. The need for these deed restrictions may be reevaluated at the time of transfer in the event that contamination no longer poses an unacceptable risk under residential use.

The preparation of a Remedial Design/Remedial Action Work Plan would cost $\$ 150,000$. The cost for excavation, transportation, disposal fees, and backfilling would be $\$ 932,000$. The total cost for 
this would be $\$ 1,084,000$, including $\$ 2,000$ for recording the deed notifications and restrictions. The risk to future workers and possible future residents would be reduced to less than $1 \times 10^{-6}$ from ingestion of PCB-1260 contaminated soil.

\section{Section V.B Preferred Alternative}

Based on the BRA, the DBRP unit soil poses a risk of $1 \times 10^{-5}$ for possible future residents via ingestion of the soil in the top 2 foot layer. This risk, however, is reduced to $1 \times 10^{-6}$ for future workers in an industrial land use scenario. Inhalation and ingestion of groundwater pose risks of $1 \times 10^{-3}$ for future residents and $3 \times 10^{-4}$ for future on-unit workers. Under institutional controls, the local groundwater would not be used for drinking or hygiene. Therefore, the preferred action at the DBRP is to use Institutional Controls (Alternative 2).

Implementation of this alternative will require both short- and long-term actions. For the short-term, signs will be posted indicating that this area was used to manage hazardous materials. In addition, existing SRS access controls will be used to maintain the use of this site for industrial use only.

In the long-term, if the property is ever transferred to non-federal ownership, the U.S. Government will, in compliance with Section 120(h) of CERCLA, create a deed for the new property owner. : The deed shall include notification disclosing former waste management and disposal activities as well as remedial actions taken on the site. The deed notification shall, in perpetuity, notify any potential purchaser that the property has been used for the management and disposal of nonhazardous, inert construction debris, and that wastes containing hazardous substances, such as degreasers and solvents, were also managed and burned on the site.

The deed shall also include deed restrictions precluding residential use of the property. However, the need for these deed restrictions may be reevaluated at the time of transfer in the event that contamination no longer poses an unacceptable risk under residential use.
In addition, if the site is ever transferred to nonfederal ownership, a survey plat of the area will be prepared, certified by a professional land surveyor, and recorded with the appropriate county recording agency.

The Institutional Controls Alternative is intended to be the final action for the DBRP unit. The solution is intended to be permanent and effective in both the long and short terms. This alternative is considered to be the least cost option which is still protective of human health and the environment.

This proposal is consistent with EPA guidance and is an effective use of risk management principles. This Statement of Basis/Proposed Plan provides for involvement with the community through a document review process and a publis comment period. Public input will be documented in the Responsiveness Summary of the Record of Decision and RCRA permit modifications, as previously discussed. To submit written or oral comments, please refer to Section II.

DOE will draft a plan for continued annual groundwater monitoring, during the second quarter of each calendar year, for the five wells at the DBRP. This groundwater monitoring plan will be appended to the ROD.

$$
\because \because
$$

The samples will be analyzed for the chemicals which were modeled to be significant risk and hazard drivers in the BRA or were identified in the fate and transport modeling as potential offenders. The list of analytes will include:

$$
\begin{aligned}
& \text { arsenic } \\
& \text { benzene } \\
& \text { benzo(a)anthracene } \\
& \text { benzo(a)pyrene } \\
& \text { benzo(b)fluoranthene } \\
& \text { benzo(k)fluoranthene } \\
& \text { chromium } \\
& \text { chrysene } \\
& \text { 1,2-dichloroethane } \\
& \text { dichloromethane } \\
& \text { endrin } \\
& \text { manganese } \\
& \text { octachlorodibenzo-p-dioxin } \\
& \text { PCB-1260 } \\
& \text { total alpha emitting radium } \\
& \text { 1,1,2-trichloroethane }
\end{aligned}
$$


The data from the annual sampling events will be included in the five year ROD reviews. Any of these analytes, which is not detected during a five year monitoring and review cycle, will be dropped from the list for subsequent cycles. If there are no exceedances of maximum contaminant levels by any of the analytes during the preceding five year period, indicating no appreciable leaching to groundwater of these chemicals, SRS will request SCDHEC and EPA concurrence for the termination of groundwater monitoring. 


\section{REFERENCES}

DOE (U. S. Department of Energy), 1994. Public Involvement, A Plan for Savannah River Site. Savannah River Operations Office, Aiken, South Carolina (1994).

DOE, 1996. Savannah River Site Future Use Project Report, Stakeholder Recommendations for SRS Land and Facilities (U). Savannah River Operations Office, Aiken, South Carolina (January 1996).

EPA, 1990. (U. S. Environmental Protection Agency). A Guide on Remedial Actions at Superfund Sites with $P C B$ Contamination. Office of Emergency and Remedial Response. Directive 9355.4-01 FS (August 1990).

EPA, 1995. Supplemental Guidance to RAGS: Region 4 Bulletins; Development of RiskBased Remedial Options; Human Health Risk Assessment Bulletin No. 5 (November 1995).

Federal Facility Agreement, $1993 . \quad$ Federal Facility Agreement for the Savannah River Site, Administrative Docket No. 89-05-FF, (Effective Date: August 16, 1993).

WSRC (Westinghouse Savannah River Company), 1994. Data Summary Report for the D-Area Burning/Rubble Pits. WSRC-RP-94-709, Rev. 0 , Westinghouse Savannah River Company, Aiken, South Carolina (1994).

WSRC, 1995a. Baseline Risk Assessment for the D-Area Burning/Rubble Pits (U). WSRC-TR94-708, Rev. 1, Westinghouse Savannah River Company, Aiken, South Carolina (1995).

WSRC, 1995b. RFI/RI Report for D-Area Burning/Rubble Pits (43I-D and 43I-ID)(U). WSRC-RP-94-707, Rev. 1, Westinghouse Savannah River Company, Aiken, South Carolina (1995).
WSRC, 1996a. F-Area Burning/Rubble Pits (231F, 231-1F, and 231-2F) Corrective Measures Study/Feasibility Study (U). WSRC-RP-95660, Rev. 1), Westinghouse Savannah River Company, Aiken, South Carolina (March 1996).

WSRC, 1996b. D-Area Burning/Rubble Pits (431$D$ and 43I-ID) Corrective Measures Study/Focused Feasibility Study (U). WSRCRP-95-904, Rev. 1, Westinghouse Savannah River Company, Aiken, South Carolina (March 1996). 


\section{GLOSSARY}

Administrative Record File: A file that is maintained and contains all information used to make a decision on the selection of a response action under the Comprehensive Environmental Response, Compensation \& Liability Act. This file is to be available for public review, and a copy is to be established at or near the Site, usually at one of the information repositories. Also a duplicate file is held in a central location, such as a regional or state office.

ARARs: Applicable, or Relevant and Appropriate Requirements: Refers to the federal and state requirements that a selected remedy will attain. These requirements may vary from site to site.

Baseline Risk Assessment: Analysis of the potential adverse health effects (current or future) caused by hazardous substance release from a site in the absence of any actions to control or mitigate these releases.

Characterization: The compilation of all available data about the waste units to determine the rate and extent of contaminant migration resulting form the waste site, and the concentration of any contaminants that may be present.

Comprehensive Environmental Response, Compensation and Liability Act (CERCLA), 1980: A Federal law passed in 1980 and modified in 1986 by the Superfund Amendments and Reauthorization Act. The Acts created a special tax that goes into a Trust Fund, commonly known as Superfund, to investigate and clean up abandoned or uncontrolled hazardous waste sites.

Corrective Action: An EPA requirement to conduct remedial procedures' under RCRA 3998(h) at a facility when there has been a release of hazardous waste or constituents into the environment. Corrective action may be required beyond the facility boundary and can be required regardless of when the waste was placed at the facility.
Exposure: Contact of an organism with a chemical or physical agent. Exposure is quantified as the amount of the agent available at the exchange boundaries of the organism (e.g., skin, lungs, digestive tract, etc.) and available for absorption.

Federal Facility Agreement (FFA): The legally binding agreement between regulatory agencies (EPA and SCDHEC) and regulated entities (DOE) that sets the standards and schedules for the comprehensive remediation of the SRS.

Media: A pathway through which contaminants are transferred. Five media by which contaminants may be transferred are groundwater, soil, surface water, sediments, and air.

National Priorities List (NPL): EPA's formal list of the nation's most serious uncontrolled or abandoned waste sites, identified for possible long-term remedial response, as established by. CERCLA.

Operable Unit (OU): A discrete action taken as one part of an overall site cleanup. The term is also used in EPA guidance documents to refer to distinct geographic areas or media-specific units within a site. A number of operable units can be used in the course of a cleanup.

Operation and Maintenance (O\&M): Activities conducted at a site after a response action occurs to ensure that the cleanup and/or systems are functioning properly.

Overall Protection of Human Health and the Environment: The assessment against this criterion describes how the alternative, as a whole, achieves and maintains protection of human health and the environment.

Proposed Plan: A legal document that provides a brief analysis of remedial alternatives under consideration for the site/operable unit and proposes the preferred alternative. It actively solicits public review and comment on all alternatives under consideration. 
Record Of Decision (ROD): A legal document that explains to the public which alternative will be used at a site/operable unit. The record of decision is based on information and technical analysis generated during the remedial investigation/feasibility study and consideration of public comments and community concerns.

Resource Conservation and Recovery Act (RCRA), 1976: A Federal law that established a regulatory system to track hazardous substances from their generation to disposal. The law requires safe and secure procedures to be used in treating, transporting, storing, and disposing of hazardous substances. RCRA is designed to prevent the creation of new, uncontrolled hazardous waste sites.

Responsiveness Summary: A summary of oral and/or written comments received during the proposed plan comment period and includes responses to those comments. The responsiveness summary is a key part of the ROD, highlighting community concerns.

Statement of Basis/Proposed Plan (SB/PP): A legal document that provides a brief analysis of remedial alternatives under consideration for the site/operable unit and proposes the preferred alternative. This integrated RCRA/CERCLA document actively solicits public review and comment on all alternatives under consideration.

Superfund: The common name used for CERCLA; also referred to as the Trust Fund. The Superfund program was established to help fund cleanup of hazardous waste sites. It also allows for legal action to force those responsible for the sites to clean them up. 